Jurnal Keperawatan Silampari

Volume 3, Nomor 2, Juni 2020

e-ISSN: 2581-1975

p-ISSN: 2597-7482

DOI: https://doi.org/10.31539/jks.v3i2.1091

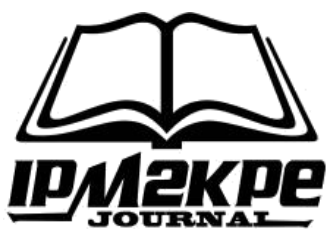

\title{
TERAPI MUROTAL DALAM UPAYA MENINGKATKAN KUALITAS TIDUR LANSIA
}

\author{
Ricky Riyanto Iksan ${ }^{1}$, Eni Hastuti ${ }^{2}$ \\ Akademi Keperawatan Pelni Jakarta ${ }^{1,2}$ \\ kykyiksan@gmail.com ${ }^{1}$
}

\begin{abstract}
ABSTRAK
Tujuan penelitian untuk mengetahui gambaran analisa terapi murottal pada lansia, memberikan gambaran tentang murottal dalam upaya meningkatkan kualitas tidur lansia, mengetahui kualitas tidur lansia sebelum dan sesudah melakukan terapi murottal. Desain penelitian yang di gunakan merupakan rancangan deskriptif dalam bentuk study kasus. Hasil Penelitian pada subjek I dan II dapat dilihat perbedaan hasil akan tetapi keduanya mengalami penurunan frekuensi terbangun dan durasi mendengarkan murottal denagn hasil sebagai berikut, subjek II mengalami proses tidur dari terapi murottal yang lebih cepat yakni dengan mendengarkan murottal 12 menit 27 detik subjek mampu tertidur sedangkan subjek I mengalami proses tidur diwaktu 13 menit 25 detik. Simpulan, proses menua merupakan proses alami yang disertai adanya penurunan kondisi fisik lansia salah satunya yaitu perubahan tidur lansia.
\end{abstract}

Kata Kunci: Al-Qur'an, Kualitas Tidur Lansia, Terapi Murottal

\section{ABSTRACT}

The purpose of this study was to determine the analysis of marital therapy in the elderly, to provide an overview of mutual to improve the quality of sleep in the elderly, to find out the quality of sleep in the elderly before and after performing complementary therapy. The research design used is descriptive in the form of case studies. Results of research on subjects I and II can be seen differences in outcomes. Still, both of them experienced a decrease in the frequency of awakening and the duration of listening to mutual with the following results. Subject II experienced the sleep process of complementary therapy, which is faster by looking to shared 12 minutes 27 seconds. The subject can fall asleep while the subject I had a sleep process of 13 minutes 25 seconds. Conclusion, the aging process is a natural process accompanied by a decrease in the physical condition of the elderly, one of which is the change in the elderly's sleep

Keywords: Al-Qur'an, Elderly Sleep Quality, Murottal Therapy 


\section{PENDAHULUAN}

Lansia merupakan suatu proses alami yang ditentukan oleh Tuhan Yang Maha Esa. Menjadi tua merupakan proses alamiah yang berarti seseorang telah melalui tahaptahap kehidupannya, yaitu neonatus, toddler, pra school, school, remaja, dewasa dan lansia Indonesia sebagai negara berkembang kontribusi terbanyak lansia yaitu dari provinsi Yogyakarta, dimana jumlah lansia tahun 2017 adalah $(13,81 \%)$ (Kemenkes, 2017)

Menurut data WHO, sekitar 972 juta orang atau 26,4\% orang di dunia memiliki penyakit hipertensi, sehingga angka ini kemungkinan akan meningkat menjadi $29,2 \%$ di tahun 2025. Dari 972 juta orang yang menderita penyakit hipertensi di dunia, di negara maju terdapat sekitar 333 juta dan di negara berkembang 639 juta, dan salah satunya Indonesia. Pada usia lanjut banyak yang menderita hipertensi, pada usia 55-64 dengan prevalensi 45,9\% tahun, pada usia 65 yaitu 57,6\%, dan pada usia di atas75 tahun yaitu 74\% dan 63,8\% (Kemenkes, 2017).

Prevalensi penduduk lansia tahun 2017 menurut jenis kelamin bahwa lansia perempuan berjumlah 9,53\% sedangkan lansia laki-laki bejumlah 8,54\% (Kemenkes, 2017). Sedangkan pada tahun 2015 jumlah lansia perempuan berjumlah 9,0\% sedangkan lansia laki-laki berjumlah $8,0 \%$. Data lain dari survey yang dilakukan mahasiswa Akper Pelni Jakarta yang dimulai pada Bulan November 2018 sampai dengan Desember 2018 dengan jumlah 167 kepala keluarga terdapat 90 jiwa lansia yang berada di kelurahan Slipi (Akper Pelni, 2018).

Masalah kesehatan umum pada lansia yaitu osteoarthritis $62,40 \%$, hipertensi $41,70 \%$, gangguan gigi dan mulut $24,5 \%$, gangguan mental $23,55 \%$, gangguan kardiovaskuler $20,30 \%$, gangguan penglihatan 20,70\%, hiperurisemia $15,70 \%$, insomnia $12,60 \%$, hiperlipidemia $10,70 \%$, gangguan pendengaran $9,90 \%$, dan diabetes mellitus 3.4\% (Mahlufi, 2016). Lansia juga mengalami masalah kesehatan lainnya yang meliputi kemunduran dan kelemahan baik kemunduran fisik, kognitif, perasaan, mental, dan social (Andri et al., 2019).

Waktu tidur menurun dengan tajam setelah seseorang memasuki masa tua. Disamping itu juga mereka harus menyesuaikan diri dengan perubahan-perubahan secara fisik, fisiologis, dan psikologis yang cenderung bergerak ke arah yang lebih buruk (Setyowati, 2017).

Salah satu penyebab gangguan tidur pada lansia adalah keadaan dimana seseorang mengalami perubahan dalam pola istirahatnya. Salah satu penyebabnya fleksibilitas sendi pada lansia sehingga menimbulkan dampak berupa nyeri. Terjadi erosi pada kapsul persendian, sehingga akan menyebabkan penurunan luas dan gerak sendi, yang akan menimbulkan gangguan berupa pembengkakan dan nyeri gangguan tidur pada lansia adalah penyakit hipertensi. Untuk menangani kasus ini penulis menggunakan terapi non farmakologi yaitu dengan terapi murottal Al-Qur'an. Hasil penelitian yang dilakukan Aji (2016) menyimpulkan adanya hubungan signifikan antara kualitas tidur dengan hipertensi pada usia lanjut di Posyandu Lansia Dusun Jelapan Sindumartani Ngemplak Sleman. Keeratan hubungan antara kualitas tidur dengan hipertensi pada usia lanjut tersebut bersifat kuat . Dari 35 responden yang mempunyai kualitas tidur dengan kategori buruk mayoritas memiliki tekanan darah tinggi dengan grad sedang yaitu sebanyak 22 orang atau $(62,8 \%)$.

Dari penjelasan sebelumnya menyebutkan bahwa lansia dapat beresiko mengalami gangguan tidur. Lansia perlu tidur teratur untuk melindungi fungsi tubuh mereka dan untuk mempertahankan kualitas hidup mereka dengan cara sebaik mungkin. 
Perawatan untuk gangguan tidur pada lansia termasuk penggunaan metode farmakologis dan nonfarmakologis yang mudah diterapkan, praktis, dan murah yang dapat digunakan dalam praktik keperawatan (Sarikaya, Oguz, 2016).

Penanganan yang dapat dilakukan untuk meningkatkan kualitas tidur pasien yaitu terapi pengaturan tidur, terapi psikologi dan terapi relaksasi. Terapi relaksasi yang termasuk adalah napas dalam, relaksasi otot progresif, latihan pasrah diri, terapi musik dan aromaterapi. Murottal Al-Quran merupakan salah satu terapi musik yang dapat didengarkan seseorang sehingga dapat memberikan pengaruh positif (Widaryati, 2018).

Penelitian Oktara et al., (2016) terdapat pengaruh terapi murottal Al Qur'an terhadap kualitas tidur lansia. Sejalan dengan penelitian Marlina, Sudyasih (2019) Ada pengaruh terapi murottal Al-quran secara audio visual terhadap kualitas tidur lansia dengan insomnia di Panti Wredha Budhi Dharma Umbulharjo Yogyakarta.

Penelitian Riyanti et al., (2019) menunjukkan bahwa hasil penelitian terdapat perbedaan yang bermakna antara kualitas tidur sebelum dan sesudah pemberian terapi murottal Al-Quran irama nahawand ( $p$ value 0,003 ).

Penelitian Nadhifatus (2018) menunjukkan bahwa ada pengaruh terapi murottal Al Qur'an terhadap kualitas tidur lansia dipengaruhi oleh kelebihan terapi murottal Al Qur'an dengan tempo yang lambat serta harmonis lantunan Al Qur'an dapat menurunkan hormon stres, mengaktifkan hormon endorfin alami, meningkatkan perasaan rileks, dan mengalihkan perhatian dari rasa takut, cemas dan tegang, memperbaiki sistem kimia tubuh sehingga menurunkan tekanan darah serta memperlambat pernafasan, detak jantung, denyut nadi, dan aktivitas gelombang otak.

Pemberian murattal Al-Qurean surat Ar-Rahman dapat memberikan perasaan tenang yang dapat membantu lansia untuk tidur (Firdaus, Santoso, 2018). Sejalan dengan penelitian Febiyanti, Komarudin (2017) bahwa mendengarkan murattal AlQurean surat Ar-Rahman dapat memberikan rasa optimis, damai, percaya diri dan ketenangan yang dapat merangsang hipotalamus untuk menstimulasi kelenjar anterior pituitary sehingga dapat menurunkan sekresi Adrenocorticotropic hormone (ACTH) yang menyebabkan sekresi hormon kortisol menurun rasa nyeri dan kecemasan berkurang.

Berdasarkan hasil studi pendahuluan yang dilakukan oleh peneliti pada 15 Maret 2018 di Panti Wredha cibubur didapatkan data jumlah lansia 59 orang dengan jenis kelamin laki-laki berjumlah 20 orang, sedangkan jumlah perempuan 39 orang. Didapatkan informasi wawancara sebanyak 8 orang bahwa lansia di Panti Wredha cibubur, 7 diantara 8 lansia mengalami kualitas tidur yang buruk, mereka mengatakan susah dalam memulai tidur, sering terbangun pada malam hari, terkadang sering terbangun awal, sulit untuk memulai tidur kembali, dan frekuensi tidur lansia rata - rata di panti berkisar $4-5$ jam, yang normalnya frekuensi tidur pada lansia adalah 6 jam per hari. Sekitar 87,5 \% lansia mengalami insomnia di Panti Whreda Budhi Dharma.

Berdasarkan penelitian sebelumnya berbagai cara menangani gangguan tidur lansia selama ini banyak menggunakan terapi farmakologi obat-obatan seperti pemberian obat CTM (Chlorphheniramin Maelat), sering mendengarkan radio, menonton $\mathrm{tv}$, dan hanya tidur-tiduran saja ditempat tidur, namun penelitian ini menekankan dengan menggunakan Murottal Al-Quran sebagai terapi untuk tidur mereka karena terapi ini belum pernah dilakukan di tempat penelitian. 


\section{METODE PENELITIAN}

Penelitian Ini merupakan rancangan deskriptif dalam bentuk studi kasus. Yang mencakup pengkajian satu unit penelitian secara intensif, misal satu pasien, keluarga, kelompok, komunitas, atau institusi. Meskipun jumlah subyek cenderung sedikit, jumlah variabel yang diteliti sangat luas. Penelitian ini melibatkan 2 individu yaitu dua pasien lansia dengan gangguan tidur yang dipilih secara purposive random sampling. Purposive sampling adalah penelitian berdasarkan kriteria yaitu kriteria ketentuan yang diharapkan dan sampel dipilih berdasarkan kriteria tersebut. Unit sampling diseleksi untuk tujuan tertentu, oleh karena itu digunakan istilah purposeful atau purposive.

Pada penelitian ini peneliti melakukan intervensi terapi murottal dalam upaya meningkatkan kualitas tidur lansia terhadap dua lansia dengan karakteristik yang sama yaitu kedua klien sama-sama melakukan terapi murottal selama10 hari selama 20-25 menit. Fokus studi adalah kajian utama dari masalah yang akan dijadikan titik acuan penelitian. Fokus studi dari penelitian ini adalah"Perubahan kualitas tidur lansia yang mendapat intervensi terapi murottal". Perubahan kualitas tidur lansia yang disebabkan oleh faktor usia , kualiatas tidur seiring dengan bertambahnya usia secara progresif akan menurun karena penurunan kapasitas untuk menginisiasi dan menjaga tidur hal ini yang menyebabakan lansia bangun di malam hari.

\section{HASIL PENELITIAN}

Tabel.1

Frekuensi Terbangun dan Lama Tidur Durasi Pemberian Murotal

\begin{tabular}{|c|c|c|c|}
\hline No & Aspek & Sebelum & Sesudah \\
\hline 1. & Frekuensi terbangun & $\begin{array}{l}\text { Sebelum dilakukan } \\
\text { intervensi muroral } \\
\text { subyek terbangun di } \\
\text { malam hari seanyak } \\
7 \mathrm{x}\end{array}$ & $\begin{array}{l}\text { Setelah dilakukan } \\
\text { intervensi selama } 10 \\
\text { hari berturut-turut } \\
\text { terbangun di malam } \\
\text { hari sebanyak 3x }\end{array}$ \\
\hline 2. & Lama tidur & $\begin{array}{l}\text { Saat di wawancara } \\
\text { subyek lama tidur } 3 \\
\text { jam }\end{array}$ & $\begin{array}{l}\text { Setelah } \\
\text { intervensi } \\
\text { murotal selama } 10 \\
\text { hari berturut }- \text { turut } \\
\text { lama tidur } 5 \text { jam } 10 \\
\text { menit }\end{array}$ \\
\hline 3. & Durasi pemberian murotal & $\begin{array}{l}\text { Subyek tertidur di hari } \\
\text { pertama pemberian } \\
\text { terapi dengan } 18 \text { jam } \\
14 \text { detik }\end{array}$ & $\begin{array}{lr}\text { Setelah } & \text { dilakukan } \\
\text { intervensi } & \text { terapi } \\
\text { murotal selama } 10 \\
\text { hari berturut turut } 12 \\
\text { menit } 27 \text { detik }\end{array}$ \\
\hline
\end{tabular}

Pada tabel 1 di atas subyek penelitian merasa lebih rileks saat terbangun, subyek merasa murottal membantu meringankan sakit kepala karena subjek mempunyai riwayat vertigo dan hipertensi. Di pertemuan ke 1 frekuensi terbangun sebelum dilakukan intervensi muroral subyek terbangun di malam hari seanyak $7 \mathrm{x}$ ketika setelah dilakukan intervensi selama 10 hari berturut-turut terbangun di malam hari sebanyak 3x Lama tidur sebelum dilakukan intervensi tidur 3 jam setelah dilakukan intervensi terapi murotal selama 10 hari berturut - turut lama tidur 5 jam 10 menit durasi pemberian murotal sebelum subyek tertidur di hari pertama 
pemberian terapi dengan 18 jam 14 detik setelah dilakukan intervensi terapi murotal selama 10 hari berturut turut 12 menit 27 detik.

\section{PEMBAHASAN}

Pada subyek penelitian I, ditemukan dampak lingkungan yang berdampak pada kualitas tidur lansia, yaitu adanya hambatan yang terdapat pada lingkungan berupa subjek tinggal bersama 3 anak mantu dan 3 cucu subjek, dan mempunyai kebiasaan nonton TV hingga larut malam.

Pada subjek penelitian II, ditemukan dampak lingkungan dimana terdapat hambatan pada lingkungan berupa yakni kurang adanya perhatian dari anak yang tinggal satu rumah dengan subjek, pola tidur yang panjang di siang hari yang menyebabkan kualitas tidur subjek pada malam hari pendek. Insomnia merupakan gejala yangdialami seseorang kesulitan tidur mengeluh rasa kantuk yang berlebih di siang hari yang mengakibatkan kualitas dan kuantitas tidur dimalam hari yang tidak cukup.

Hasil penelitian Oktara et al., (2016) yang menyatakan bahwa terdapat perbedaan antara kualitas tidur pada lansia sebelum dan sesudah diberikan terapi murottal dengan (p-value 0,000), sedangkan pada kelompok kontrol tidak ada perbedaan antara kualitas tidur lansia sebelum dan sesudah dilakukan pengamatan dengan hasil ( $\mathrm{p}$-value $=0,083$ ). Kesimpulan pada penelitian ini terdapat pengaruh pemberian terapi murotal Al-Quran terhadap kualitas tidur pada lansia.

Terapi musik adalah suatu metode perawatan terkelola yang dikelola secara terorganisir untuk mengoptimalkan efek psikologis dan fisik dari suara dan melodi musik untuk mengobati berbagai gangguan mental. Musik adalah suatu metode yang tersebar luas yang digunakan untuk mengobati penyakit dalam masyarakat. Musik dapat meringankan penyakit fisik dengan menurunkan detak jantung, suhu tubuh, tekanan darah, dan laju pernapasan. Tujuan terapi musik adalah untuk mengubah suasana hati dan mengurangi stres, rasa sakit, dan tingkat kecemasan. Oleh karena itu, terapi musik dapat meningkatkan kualitas hidup dan membantu orang untuk mengekspesikan diri secara lebih bebas (Sarikaya, Oguz, 2016).

Hasil penelitian yang dilaksanakan setelah 10 hari melakukan terapi muottal, maka hasil dari subyek penelitian I, mengalami peningkatan lama tidur 7 jam 30 menitwaktu mendengarkan murottal 13 menit 25 detik subjektidak terbangun di malam hari, terdapat penurunan durasi mendegarkan murottal sebanyak 6 menit 16 detik pada subyek penelitian II, mengalami peningkatan lama tidur 5 jam 30 menit waktu mendengarkan murottal 12 menit 27 detik subjek tidak terbangun 3 kali, terdapat penurunan durasi mendegarkan murottal sebanyak 5 menit 17 detik.

Dari hasil hasil diatas dapat disimpulkan pada subjek I dan II dapat dilihat perbedaan hasil akan tetapi keduanya mengalami penurunan frekuensi terbangun dann durasi mendengarkan murottal denagn hasil sebagai berikut, subjek II mengalami proses tidur dari terapi murottal yang lebih cepat yakni dengan mendengarkan murottal 12 menit 27 detik subjek mampu tertidur sedangkan subjek I mengalami proses tidur diwaktu 13 menit 25 detik. Subjek II mengalami penurunan terbangun saat malam hari sebanyak 3 kali sedangkan subjek I tidak ada frekuensi terbangun di malam hari. subjek II mengalami durasi tidur 5 jam 30 menit dan subjek I selama 7 jam 30 menit.

Penelitian yang dilakukan Selinandani, Isnaeni (2018) Kualitas tidur sebelum pemberian terapi audio murottal Surah ArRahman memiliki kualitas tidur buruk (100\%). Sedangkan kualitas tidur setelah pemberian terapi audio murottal Surah Ar- 
Rahman memiliki hasil kualitas tidur baik $(91,7 \%)$. Hasil uji Wilcoxon didapat $p$-value sebesar 0,002 < 0,05 sehingga pemberian terapi audio murottal Surah Ar-Rahman berpengaruh terhadap kualitas tidur usia lanjut.

Kelebihan terapi murottal Al Qur'an dengan tempo yang lambat serta harmonis lantunan Al Qur'an dapat menurunkan hormon stres, mengaktifkan hormon endorfin alami, meningkatkan perasaan rileks, dan mengalihkan perhatian dari rasa takut, cemas dan tegang, memperbaiki sistem kimia tubuh sehingga menurunkan tekanan darah serta memperlambat pernafasan, detak jantung, denyut nadi, dan aktivitas gelombang otak (Nadhifatus, 2018).

Mendengarkan lantunan Al-Quran memiliki hasil yang sama seperti mendengarkan terapi musik santai dalam hal patofisiologi mekanisme rangsangan auditori. Sistem limbik serebral (aksis hipotalamus-hipofisi-adrenal dan kompleks amygladoid) memediasi keterlibatan audio melalui jalur sistem pendengaran ke area pendengaran, khususnya jalur sarah (sirkuit emosi). Rangsangan audio membangkitkan tanggapan psikofisiologis karena pengaruhnya pada sistem limbik yang mungkin merangsang sekresi beberapa hormon seperti serotonin, dopamin, dan atau norepinefrin pada sinapsis, akhirnya melepaskan stres. Rangsangan audio Al-Quran berfungsi sebagai pedoman hidup seorang muslim. Audio AlQuran memiliki efek dalam mensekresi hormon-hormon (Pramesona, Taneepanichskul, 2018).

Selain itu, suara murottal ini akan mengaktifkan dan mengendalikan sraf otonom. Saraf otonom tersebut mempunyai dua sistem saraf yaitu saraf simpatis dan saraf parasimpatis. Sistem saraf simpatis berfungsi untuk mempersyarafi jantung dan memperlambat detak jantung, sedangkan saraf parasimpatis sebaliknya. Kedua sistem saraf ini mempengaruhi relaksasi atau ketenangan. Relaksasi atau ketenangan tersebut menjadikan midbrain akan melepaskan serotonin, enkhephalin, betaendorphin dan zat lainnya ke dalam sirkulasi (Nafi'ah, Dewi, 2016).

Penelitian Noorika (2018) setelah dilakukan terapi murotal Al-Quran, pada pasien lansia mengalami penurunan tekanan darah dari $171 / 90 \mathrm{mmHg}$ menjadi $120 / 90 \mathrm{mmHg}$. Pada sistolik turun $51 \mathrm{mmHg}$ dan diastolik menetap di angka $90 \mathrm{mmHg}$. Ada pengaruh terapi murotal Al-Quran terhadap tekanan darah pada pasien lansia hipertensi di Rumah Sakit Islam Sultan Agung Semarang

Penelitian yang dilakukan Mahlufi (2016) yang dilakukan dengan tehnik wawancara yang dilakukan di Panti Wreda Dharma Bakti Surakarta didapatkan jumlah lansia yang ada dipanti 79 orang, 38 orang lansia yang mengalami gangguan tidur. Gangguan tidur yang dialami oleh lansia memiliki beberapa penyebab yang berbeda seperti kesulitan untuk tidur, sering terbangun pada malam hari dan kesulitan untuk tidur kembali setelah terbangun pada malam harinya. Hasil dari analisis bivariat menggunakan uji paired sample t-test menunjukkan nilai significancy $p=0,00 \leq 0,05$.

Hal ini diperkuat oleh penelitian Mujamil et al., (2017) bahwa dengan mendengarkan murottal 10 hingga 60 menit selama 5 hari berturut-turut pada waktu menjelang tidur malam dapat meningkatkan kualitas tidur dengan hasil sebelum mendengar murottal kualitas tidur yang baik $0 \%$, setelah mendengarkan murottal menjadi $61,1 \%$ sedangkan yang kualitas masih buruk hanya 38,9\%. Hasil penelitian tersebut menjelaskan bahwa Al-Qur`an memiliki pengaruh positif yang cukup signifikan terhadap saraf dalam menurunkan ketegangan atau stres, dan perubahan fisiologis yang sangat besar seperti penurunan depresi dan kesedihan serta memperoleh ketenangan jiwa. Pengaruh tersebut terlihat dalam bentuk perubahan energi listrik pada otot-otot organ tubuh. Perubahan tersebut juga terjadi pada daya tangkap kulit terhadap 
konduksi listrik, peredaran darah, detak jantung, volume darah yang mengalir pada kulit, dan suhu tubuh.

Penelitian Imardiani et al., (2019) menunjukkan bahwa hasil analisis statistik p value sebesar 0,000 (pvalue $<0,05$ ). Sehingga dapat disimpulkan terapi dzikir Asmaul Husna memiliki pengaruh dalam meningkatkan kualitas tidur pasien Intensif. Terapi dzikir Asmaul-Husna dapat menjadi alternative pengobatan non farmakologis dalam mengatasi masalah kualitas tidur untuk pasien ICU. Mendengarkan dzikir AsmaulHusna terdapat juga faktor keyakinan. Berdasarkan mekanismenya perambatan musik memiliki potensi untuk merespon perasaan pendengar melalui perubahan dari negatif ke positif, dan meningkatkan emosi gembira dan tenang. Sejalan dengan penelitian Nurani et al., (2019) yang menyatakan bahwa terdapat peningkatan kualitas tidur lansia menggunakan terapi murottal Al-Quran.

Sejalan dengan penelitian Reflio et al., (2016) hasil pengukuran diperoleh nilai ratarata kualitas tidur (skor PSQI) pada kelompok eksperimen sebelum dilakukan terapi dzikir adalah sebesar 14,48 dan pada kelompok kontrol sebesar 13,67. Setelah diberikan intervensi dengan terapi dzikir, terjadi penurunan rata-rata kualitas tidur (skor PSQI) yang artinya perbaikan kualitas tidur, menjadi 9,05, sedangkan pada kelompok kontrol yang tidak diberikan intervensi menjadi 13,62. Semakin kecil skor yang diperoleh maka semakin baik kualitas tidur responden dengan hasil uji statistik $p$ value $=0,000$ sehingga dapat disimpulkan terapi dzikir efektif terhadap kualitas tidur lansia

Hasil penelitian Juksen et al., (2020) didapatkan dari 27 sampel sebelum terapi murotal terdapat 19 orang lansia yang mengalami hipertensi pada tahap 1 dan 3 orang lansia hipertensi tahap 2 setelah dilakukan terapi murotal terdapat 11 orang lansia pre hipertensi terdapat 12 orang lansia dan tahap 1 dan 4 lansia hipertensi tahap 2 ada pengaruh yang signifikan antara pemberian terapi murottal terhadap penurunan tekanan darah pada lansia yang mengalami hipertensi di PSTW pagar dewa kota Bengkulu. Mengambil kesimpulan terdapat pengaruh terapi murotal terhadap penurunan tekanan darah pada lansia yang mengalami hipertensi di panti social tresna wherdha pagar dewa kota Bengkulu.

\section{SIMPULAN}

Karakteristik usia responden kelompok intervensi dan kontrol yang mengalami kualitas tidur yang buruk yaitu mayoritas berusia 60 - 68 tahun $(70 \%)$ dan mayoritas berjenis kelamin perempuan $(80 \%)$.

Terapi murottal mempunyai banyak manfaat dan sangat mudah dilakukan. Murottal Al-Quran ini juga bisa dilakukan secara rutn saat jam menjelang tidur sehingga meningkatkan kualitas tidur lansia, ketenangan yang ditimbulkan dari pemberian terapi murottal membuat lansia nyaman dan rileks sehingga terjadi peningkatan pada kualitas tidur lansia. Sesuai dengan firman Allah SWT firman Allah SWT dalam surah Al-Ra'du surah ke 13 Ada perbedaan yang bermakna kualitas tidur sebelum dan sesudah terapi murrotal Al-Qur'an pada kelompok intervensi yaitu terjadi penurunan nilai rata-rata skor kualitas tidur. 


\section{SARAN}

\section{Bagi Responden/Lansia}

Pentinganya responden lansia untuk memahami penanganan kualitas tidur yang buruk dengan menggunakan terapi Murottal AlQur'an secara Audio visual.

\section{Bagi Panti}

Terapi murrotal Al-Qur'an dapat dimasukkan ke dalam program unit rehabilitasi sebagai sebagai salah satu cara yang dapat diterapkan dalam meningkatkan kualitas tidur lansia. Pemberian terapi dapat dilakukan pada saat jam menjelang tidur.

\section{Bagi Pelayanan Keperawatan}

Perawat dapat berperan aktif dalam mengembangkan dan memilih jenis terapi yang dapat dilakukan oleh lansia dalam meningkatkan kualitas tidur lansia.

\section{Bagi Institusi Pendidikan Keperawatan}

Mengembangkan terapi murottal dalam berbagai kegiatan untuk mengahasilkan tidur lansia yang lebih baik.

\section{Bagi Peneliti}

Mampu melakukan penelitan dengan waktu durasi mendengarkan Al-Quran yang lebih cepat dari penelian yang dilakukan. Direkomendasikan untuk penelitian selanjutnya, untuk dilakukannya penelitian tentang terapi murottal dalam upaya menurunkan tekanan darah pada penderita hipertensi. Diharapkan bagi peneliti selanjutnya dapat melakukan penelitian pada variabel lain yang berhubungan dengan kualitas tidur maupun tekanan darah atau dapat melakukan penelitian pada variabel pengganggu yang belum diteliti.

\section{Bagi Ilmu Pengetahuan}

Hasil penelitian ini diharapkan dapat memperkaya ilmu pengetahuan dalam bidang keperawatan dan dapat dijadikan sebagai sumber pembelajaran, sebagai terapi berbasis bukti, dan sebagai bentuk publikasi

\section{DAFTAR PUSTAKA}

Aji, M. N. R. P. (2016). Hubungan Kualitas Tidur dengan Hipertensi pada Usia Lanjut di Posyandu Lansia Dusun Jelapan Sindumartani Ngemplak Sleman Daerah Istimewa Yogyakarta. In Universitas Aisyiyah. https://doi.org/10.1017/CBO9781107415324.004

Akper Pelni. (2018). Hasil Survey Kesehatan Mayarakat Akper Pelni Tahun 2018

Andri, J., Karmila, R., Padila, P., Harsismanto, J., \& Sartika, A. (2019). Pengaruh Terapi Aktivitas Senam Ergonomis terhadap Peningkatan Kemampuan Fungsional Lansia. Journal of Telenursing, 1(2), 304-313. https://doi.org/https://doi.org/10.31539/joting.v1i2.933

Febiyanti, A., \& Komarudin, U. (2017). Murattal Al-Quran Surah ArRahman Meningkatkan Kualitas Tidur Lansia. Universitas Biokimia

Firdaus, A. N., \& Santoso, T. B. (2018). Pengaruh Perbedaan Murattal Al-Qur'an Surat Ar-Rahman dan Musik Keroncong terhadap Peningkatan Kualitas Tidur Lanjut Usia di Panti Jompo Aisyiyah Surakarta. Universitas Muhammadiyah Surakarta

Imardiani, I., Sari, A. N., \& Astuti, W. (2019). Pengaruh Terapi Dzikir Asmaul-Husna terhadap Kualitas Tidur pada Pasien Intensif di Rumah Sakit Islam Siti Khadijah Palembang. Masker Medika, 7(2), 535-542 
Juksen, F. L., Aryanto, E., \& Keraman, B. (2020). Pengaruh Terapi Murotal Surat AlKahfih terhadap Peneurunan Tekanan Darah pada Lansia yang Mengalami Hipertensi di Panti Sosial Tresna Wherdha Pagar Dewa Kota Bengkulu. Malahayati Nursing Jurnal, 2(1)

Kemenkes, R. (2017). Analisa Lansia di Indonesia. Kementrian Kesehatan RI, 1-9. www.depkes.go.id/download.php?file=download/.../infodatin lansia 2016.pdf\%0A

Mahlufi, F. (2016). Pengaruh Terapi Murottal terhadap Kualitas Tidur Penderita Insomnia pada Lanjut Usia (LANSIA) di Kecamatan Pontianak Tenggara. Eprints.Ums.Ac.Id/63666/3/BAB I.Pdf

Marlina, N. W., \& Sudyasih, T. (2019). Efektivitas Terapi Murottal Al-Qur'an Secara Audio Visual terhadap Kualitas Tidur Lansia dengan Insomnia di Panti Wredha Budhi Dharma Umbulharjo Yogyakarta. Universitas 'Aisyiyah Yogyakarta

Mujamil, J. A., Rika, H., \& Fauziah, L. (2017). Pengaruh Mendengarkan Al-Qur'an terhadap Kualitas Tidur Mahasiswa Tingkat Akhir Program Studi Sarjana Keperawatan Angkatan 2012 di STIK Immanuel Bandung. Jurnal Sehat Masada, $X I(1), 73-80$

Nadhifatus, S. (2018). Penerapan Terapi Murottal Al-Qur'an Surah Ar-Rahman 78 Ayat Pada Lansia dengan Gangguan Pola Tidur di Ruang Baitulizzah 1 Rumah Sakit Islam Sultan Agung [Universitas Islam Sultan Agung]. Repository.Unissula.Ac.Id/13763

Nafi'ah, N., \& Dewi, D. (2016). Pengaruh Terapi Murottal Al-Qur'an terhadap Tekanan Darah dan Frekuensi Denyut Jantung Pasien Pasca Operasi dengan Anastesi Umum di Rumah Sakit Umum Daerah Dr. Moewardi Surakarta

Noorika, A. D. (2018). Penerapan Prosedur Terapi Murotal Al Quran untuk Menurunkan Hipertensi pada Lansia [Universitas Islam Sultan Agung]. Repository.Unissula.Ac.Id/View/Subjects/RT.Html

Nurani, R. D., Rochmawati, E., \& Nurchayati, N. (2019). Efektifitas Terapi Murottal Al Qur'an terhadap Kualitas Tidur pada Pasien Hemodialisa. Journal of Health Studies, 3(2), 78-85. https://doi.org/10.31101/jhes.525

Oktara, S. P. D., Purnawan, I., \& Achiriyati, D. (2016). Pengaruh Terapi Murottal Al Qur'an Terhadap Kualitas Tidur Lansia di Unit Rehabilitasi Sosial Dewanata Cilacap. Jurnal Keperawatan Jenderal Soedirman Purwokerto, 11(3), 168-173

Pramesona, B. A., \& Taneepanichskul, S. (2018). The Effect of Religious Intervention on Depressive Symptoms and Quality of Life Among Indonesian Elderly in Nursing Homes: A Quasi-Experimental Study. Journal of Public Health Sciences, 13, 473-483. https://doi.org/10.2147/CIA.S162946

Reflio, R., Pristiana Dewi, A., \& Utomo, W. (2016). Pengaruh Terapi Al Zikir terhadap Kualitas Tidur Lansia. Jurnal Studi Ilmu Keperawatan Universitas Riau, 14181425. https://doi.org/http://dx.doi.org/10.4135/9781848607972.n2

Riyanti, E., Haiya, N. N., \& Ardian, I. (2019). Pengaruh Terapi Murottal Al-Quran Irama Nahawand terhadap Kualitas Tidur Lansia di Kelurahan Bangetayu Kulon Semarang. Universitas Islam Sultan Agung Semarang

Sarikaya, N. A., \& Oguz, S. (2016). Effect of Passive Music Therapy on Sleep Quality in Elderly Nursing Home Residents. Journal of Psychiatric Nursing, 7(2), 55-60. https://doi.org/10.5505/phd.2016.05900

Selinandani, D., \& Isnaeni, Y. (2018). Pengaruh Terapi Audio Murottal Surah ArRahman terhadap Kualitas Tidur Usia Lanjut di Dusun Kwarasan Nogotirto Gamping Sleman Yogyakarta. Universitas 'Aisyiyah Yogyakarta 
Setyowati, S. (2017). Pengaruh Senam Sehat Qur'ani terhadap Insomnia pada Lansia di Bantul Kepek Timbulharjo Sewon Bantul Yogyakarta. Jurnal Ilmiah Ilmu Keperawatan Dan Ilmu Kesehatan Masyarakat Surya Medika, 12(1), 18-25

Widaryati, W. (2018). Pengaruh Terapi Murotal Al Qur'an terhadap Hemodinamik dan GCS Pasien Cedera Kepala. Jurnal Kebidanan Dan Keperawatan Aisyiyah, 12(1), 77-83. https://doi.org/10.31101/jkk.128 